\title{
Age-dependence of healthcare interventions for COVID-19 in Ontario, Canada
}

\author{
Irena Papst ${ }^{\star 1}$, Michael Li²,3, David Champredon4, Benjamin M. Bolker ${ }^{2,5,6}$, Jonathan \\ Dushoff $^{2,5}$, and David J.D. Earn ${ }^{5,6,7}$ \\ ${ }^{1}$ Center for Applied Mathematics, Cornell University \\ ${ }^{2}$ Department of Biology, McMaster University \\ ${ }^{3}$ South African Centre for Epidemiological Modelling and Analysis, University of Stellenbosch \\ ${ }^{4}$ Department of Pathology and Laboratory Medicine, Western University \\ ${ }^{5}$ Michael G. DeGroote Institute for Infectious Disease Research, McMaster University \\ ${ }^{6}$ Department of Mathematics \& Statistics, McMaster University \\ ${ }^{7}$ Department of Mathematics, University of Toronto \\ *Corresponding author (email: ip98@cornell.edu) \\ Compiled on 2020-11-30 at 14:48
}

\begin{abstract}
Background: Patient age is the most salient clinical indicator of risk from COVID-19. Age-specific distributions of known SARS-CoV-2 infections and COVID-19-related deaths are available for many regions. Less attention has been given to the age distributions of serious medical interventions administered to COVID-19 patients, which could reveal sources of potential pressure on the healthcare system should SARS-CoV-2 prevalence increase.

Methods: We analysed 97,957 known SARS-CoV-2 infection records for Ontario, Canada, from 23 January 2020 to 26 November 2020 and estimated the age distributions of hospitalizations, Intensive Care Unit admissions, intubations, and ventilations. We quantified the probability of hospitalization given known SARS-CoV-2 infection, and of survival given COVID-19-related hospitalization.

Results: The distribution of hospitalizations peaks with a wide plateau covering ages 54-90, whereas deaths are concentrated in very old ages. The estimated probability of hospitalization given known infection reaches a maximum of $30.9 \%$ at age $80(95 \% \mathrm{Cl} 28.0 \%-33.9 \%)$. The probability of survival given hospitalization is near $100 \%$ for adults younger than 40 , but declines substantially after this age; for example, a hospitalized 54-year-old patient has a 91.5\% chance of surviving COVID-19 (95\% Cl 87.0\%-94.9\%).

Conclusions: Ontario's healthcare system has not been overstretched by COVID-19 thanks to widespread infection control efforts, yet the probability of survival given hospitalization for COVID-19 is lower than is generally perceived for patients over 40 . As prevalence continues to increase during this most recent wave of infection, healthcare capacities are at risk of being exceeded. Survival of individuals in the broad age range requiring acute care could decrease, potentially expanding the distribution of COVID-19related deaths toward younger ages.
\end{abstract}

Keywords: epidemiology, infectious disease, SARS-CoV-2, COVID-19, age distribution, hospitalization 


\section{Background}

Severe acute respiratory syndrome coronavirus 2 (SARS-CoV-2) was first confirmed in Ontario, Canada, on 23 January 2020, in an individual with a recent travel history to Wuhan, Hubei Province, China [1], the site of the first large-scale outbreak of this novel pathogen [2]. The virus was detected sporadically in Ontario through February [3], until the number of known infections (KIs) began to rise consistently in March. The province declared a state of emergency on 17 March 2020 [4], implementing a large-scale economic shutdown and school closures to help mitigate the spread of the virus. The province began reopening in stages through the summer [5] amid relatively low SARS-CoV-2 infection prevalence, with most schools reopening early-to-mid September [6]. In late September, additional restrictions were enacted across the province in response to the beginning of the second wave of infection [7, 8, 9], and on 23 November 2020 a lockdown was enacted in the densely populated Toronto and Peel regions [10].

A major concern associated with the spread of SARS-CoV-2 is the potential for hospitals to become overwhelmed with COVID-19, the disease caused by the virus, which would compromise care of these patients, and reduce access to and quality of care for many other illnesses. Severity of COVID-19 presentation is highly variable among individuals, but is thought to increase with age [11, 12, 13]. Deaths attributed to COVID-19 have been found to be strongly concentrated in the elderly $[14,15,16]$. Comparatively few studies have explored the age distribution of serious medical interventions administered to COVID-19 patients $[17,18]$.

55

56

57

58

59

\section{Methods}

In order to understand the potential for the healthcare system to become overwhelmed by SARS-CoV2 infections, it is important to identify the demographic groups that are most likely to require significant medical care. The goal of this study is to quantify the relationships between COVID-19 patient age and the administration of serious medical interventions (hospitalizations, intensive care unit (ICU) admissions, intubations, and ventilations) for the province of Ontario. We compare these age-intervention associations with the age distributions of Kls and deaths. We also estimate the age-specific probability of hospitalization given known SARS-CoV-2 infection, and of survival given hospitalization related to COVID-19.

We use individual-level line lists for known SARS-CoV-2 infections reported up to 26 November 2020 from the Case and Contact Management (CCM) database maintained by Public Health Ontario. This central database includes detailed records of SARS-CoV-2 infections across the entire province of Ontario. These records include an individual's demographic information (such as age), whether COVID-19-related interventions (including hospitalization, ICU admission, intubation, ventilation) were administered, as well as whether the infection was fatal.

The CCM database includes $111,210 \mathrm{KI}$ records up to 26 November 2020 . However, we analyse only KIs marked as "resolved" or "fatal" $(N=97,957)$ to avoid tallying patients whose final outcomes are not yet known. Kls are marked as "resolved" in CCM based on public health unit assessment. In all instances, a record is considered resolved if it is 14 days past the symptom onset date (or specimen collection if symptom onset date is not known), though public health occasionally performs additional follow-up to update records. For brevity, we use "resolved KIs" in our analysis to refer to Kls marked as either "resolved" or "fatal" in CCM.

These data are representative of a situation where the healthcare system was not overwhelmed with COVID-19 patients (due to wide-spread measures to keep SARS-CoV-2 spread under control). ICU occupancy for COVID-19 treatment in Ontario never exceeded more than $13 \%$ of the total ICU capacity over the period covered by the data. We calculate this percentage using daily ICU occupancy from publiclyavailable data [19] and the number of ICU (critical care) beds available according to the Government of 
medRxiv preprint doi: https://doi.org/10.1101/2020.09.01.20186395; this version posted November 30, 2020. The copyright holder for this preprint (which was not certified by peer review) is the author/funder, who has granted medRxiv a license to display the preprint in perpetuity. All rights reserved. No reuse allowed without permission.

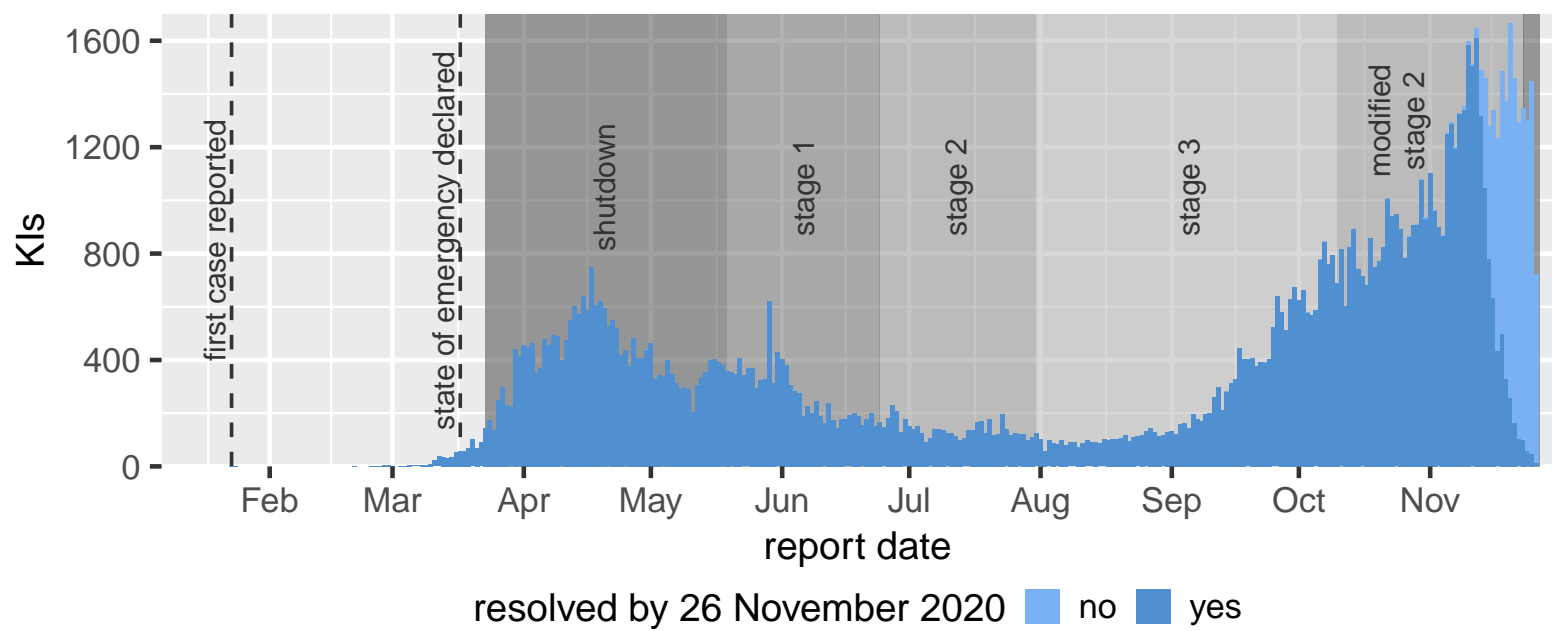

Figure 1: Known infections (KIs) over time in Ontario. Counts are split by whether or not the KI was resolved (marked as "resolved" or "fatal" in the Case and Contact Management database) by 26 November 2020 (see Methods). Dashed vertical lines mark important dates for the outbreak in the province. Shaded regions indicate roughly when the most densely populated regions were in each reopening stage (reopenings did not occur uniformly across public health units). Descriptions of each reopening stage can be found on the official Ontario COVID-19 website [5]. (panel $B$ ) as well as the count of positive tests per capita, which 
D). Testing intensity is defined as the number of tests administered per 10,000 population by age group. Controlling for demography, the number of detected infections (panel C) is relatively low in ages under 15 , increases to a relative plateau for ages 20-70 (with a noticable crest around age 25), and then continually increases after age 70. The number of resolved Kls per capita is 1.45 times higher in ages 20-29 than in ages 30-69. Testing intensity increases after age 75.

Figure 3 shows the distribution of ages for serious medical interventions (panel A) and deaths (panel B) related to COVID-19 for resolved KIs. We present raw counts, as opposed to counts normalized by the agespecific population, because the counts (not per capita counts) determine the pressure on the healthcare system. Hospitalizations are faceted by the most intensive known intervention (with ventilator use being the most intensive, followed by intubation, then ICU admission, and hospitalization). Deaths are split by whether or not the patient has a record of hospitalization for COVID-19 treatment.

The distribution of serious medical interventions is much wider than that of deaths, with the latter peaking at age 90 . Hospitalizations are relatively uniformly spread between ages 54-90, while the distribution of ICUrelated interventions (ICU admission, intubation, ventilation) is spread over a slightly younger age range. The majority of deaths, $55.3 \%$, have occurred in Kls where there is no record of hospitalization for treatment related to COVID-19.

Figure 4 shows the estimated hospitalization probability given known SARS-CoV-2 infection (panel A) and survival probability given hospitalization for COVID-19 treatment (panel B). The large uncertainty in these probability estimates for some young and very old age groups is due to small numbers of KIs and hospitalizations in these ages. The hospitalization probability peaks in the $80-81$ age group at $30.9 \%(95 \% \mathrm{Cl}$ $28.0 \%-33.9 \%$ ). In adults, the survival probability is near $100 \%$ until about age 40 , where it begins to decline steadily. For instance, a hospitalized individual in the age group 54-55 has a $91.5 \%$ chance of surviving COVID-19 (95\% Cl 87.0\%-94.9\%), implying that nearly 1 in 10 hospitalized COVID-19 patients in this age group die despite receiving medical care while ICUs and hospitals are below capacity.

\section{Discussion}

The age distribution of known SARS-CoV-2 infections (Figure 2A) and deaths attributed to COVID-19 (Figure 3B) alone provide limited insight into the risk that COVID-19 patients could overwhelm Ontario's healthcare system. The majority of COVID-19-related deaths have occurred in patients with no record of hospitalization (Figure 3B), and many deaths to date have occurred in long-term care homes, which are independent of the hospital system [25]. The broad age distributions of hospitalizations, ICU admissions, intubation, and ventilation (Figure $3 \mathrm{~A}$ ) reveal the potential pressure on the healthcare system from both middle-aged individuals and seniors.

Early in the outbreak, the province of Ontario expanded coverage for COVID-19-related treatment to include even individuals who are not usually covered by the Ontario Health Insurance Plan [26]. Access to prompt and successful medical interventions may have kept a large proportion of COVID-19-related hospitalizations from resulting in deaths. While we expect that the shape of the age distribution of the need for hospitalization (Figure 3A) would remain the same if prevalence were to increase further (as is occurring at the time of writing), the distribution of deaths (Figure 3B) may expand toward younger ages if hospitals and ICUs reach maximum capacity.

Relatively high rates of resolved Kls and testing (Figure 2C-D) in those over age 75 can be partly attributed to significant outbreaks and disease surveillance in long-term care facilities [25, 27].

The age-dependent probabilities of hospitalization given $\mathrm{KI}$ (Figure 4A) are based on resolved known infections, and so they depend on how widely SARS-CoV-2 testing has been conducted. Throughout the period covering a large portion of the CCM data, testing guidelines selected for sufficiently symptomatic individu- 
medRxiv preprint doi: https://doi.org/10.1101/2020.09.01.20186395; this version posted November 30, 2020. The copyright holder for this preprint (which was not certified by peer review) is the author/funder, who has granted medRxiv a license to display the preprint in perpetuity.

All rights reserved. No reuse allowed without permission.

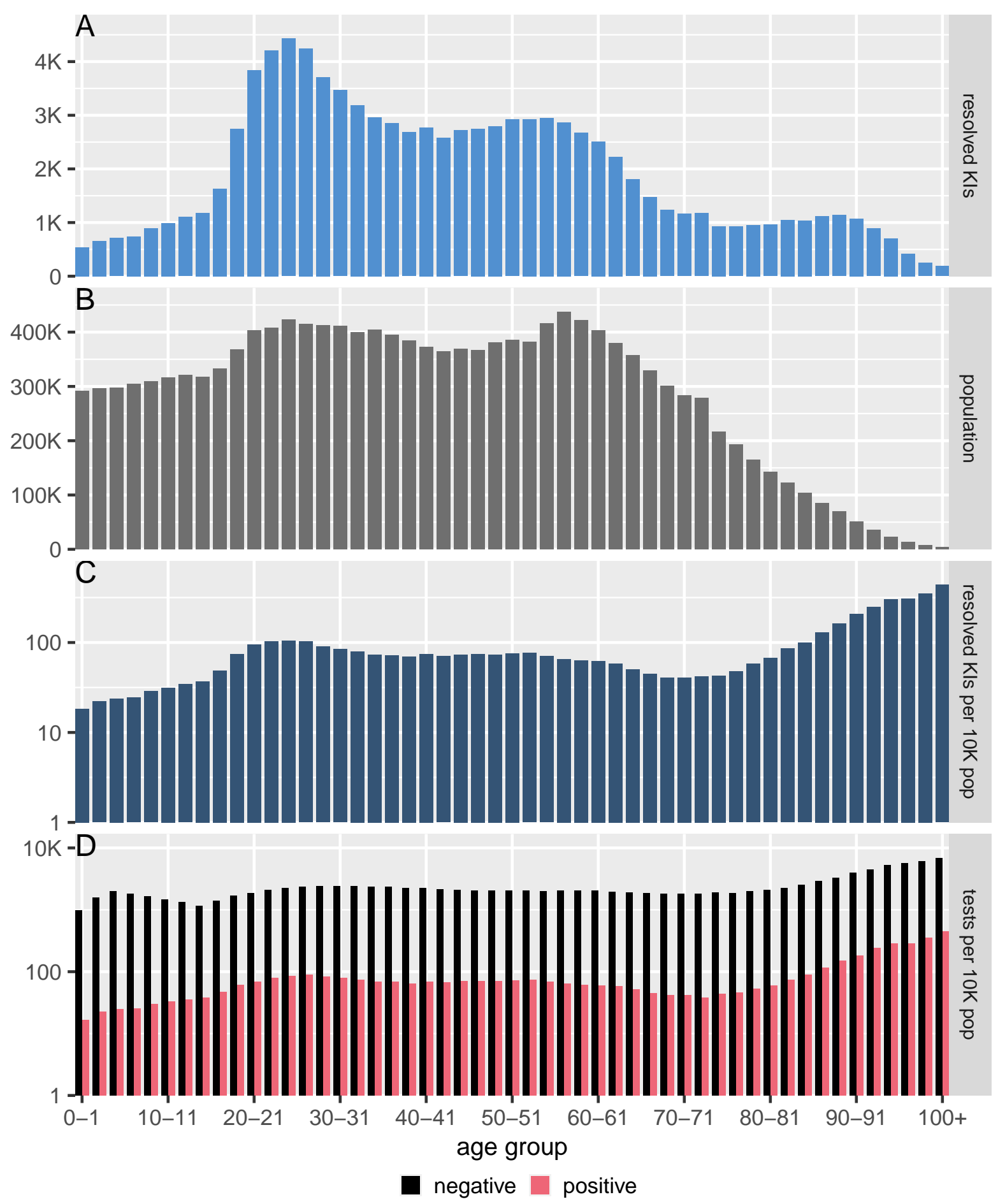

Figure 2: Age distribution of known infections (KIs) in Ontario. The distribution of ages for resolved KIs (panel A), Ontario population projections for 2020 (panel B), resolved KIs per 10,000 population (panel $C)$, and SARS-CoV-2 infection tests per 10,000 population (panel D). The $y$-axes in panels $C$ and $D$ are on a logarithmic scale.

als [28]. These guidelines were not expanded to include asymptomatic individuals from the general public until 29 May 2020 [29] and were rolled back on 24 September 2020 in an effort to preserve limited testing resources amid a surge in KIs [30]. As a result, untargetted asymptomatic testing was offered only in the 
medRxiv preprint doi: https://doi.org/10.1101/2020.09.01.20186395; this version posted November 30, 2020. The copyright holder for this preprint (which was not certified by peer review) is the author/funder, who has granted medRxiv a license to display the preprint in perpetuity. All rights reserved. No reuse allowed without permission.

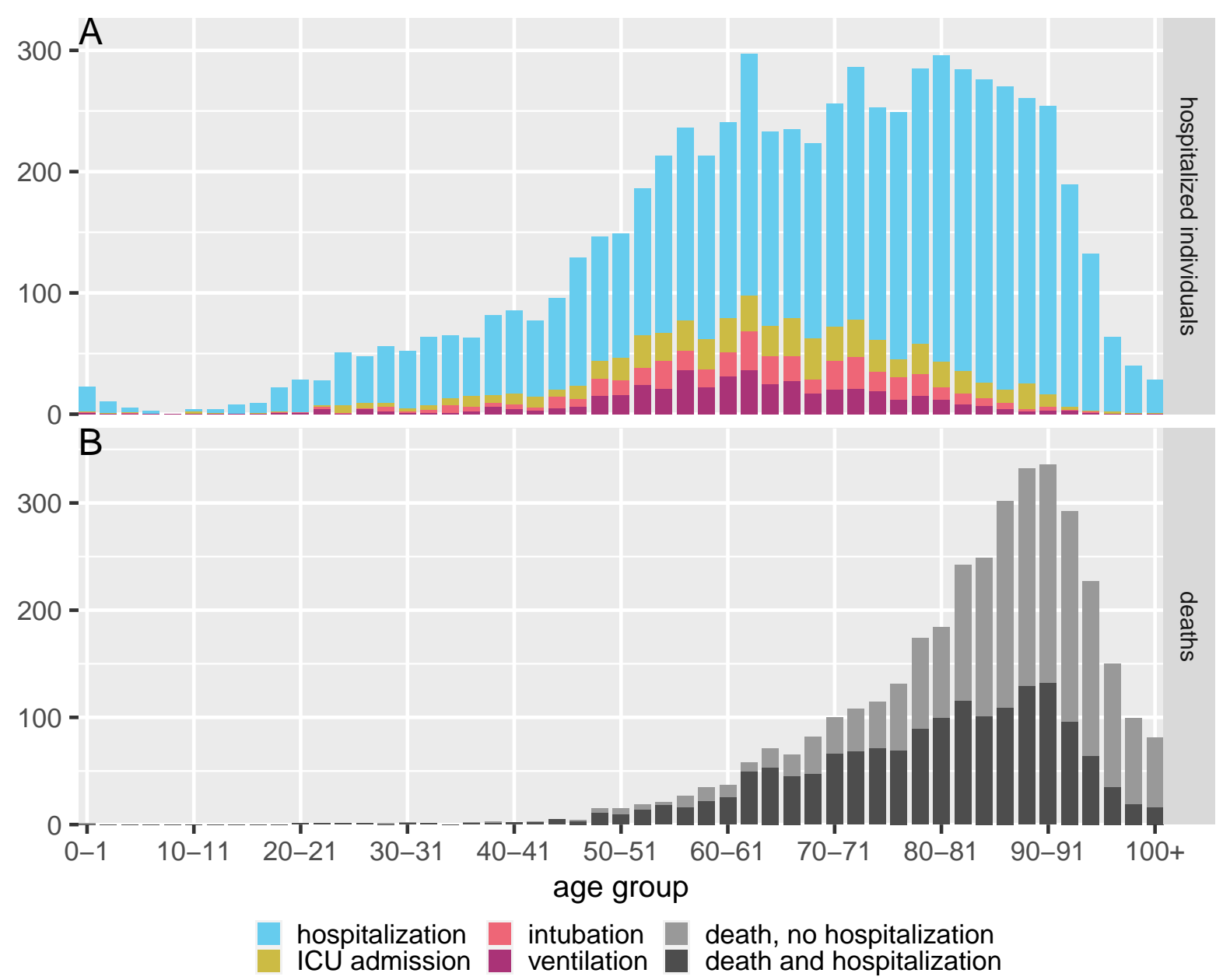

Figure 3: COVID-19 outcomes by age in Ontario. The distribution of ages for hospital interventions (panel $A)$, and deaths (panel B). Hospital outcomes are nested and tallied by the most intensive medical intervention used for each patient (ventilator use is the most intensive, followed by intubation, ICU admission, and hospitalization). Deaths are faceted by whether or not the patient also had a record of hospitalization for COVID-19 treatment.

summer, when prevalence was relatively low, which represents a small proportion of the data. Moreover, individuals may not be prompted to get tested in the absence of symptoms unless they are included in a contact tracing investigation. The probability of hospitalization given $\mathrm{KI}$ therefore likely overestimates the underlying probability of hospitalization given infection, whether known or not.

Our survival probability estimates for hospitalized individuals (Figure 4B) are not affected by the same detection biases present in KI data. Patients admitted to hospital are tested for SARS-CoV-2 as part of infection control protocols, and thus infection detection in hospitalized individuals is not influenced by testing guidelines for the general population. Our survival probability estimates do, however, represent an upper bound with respect to the current standard of care and viral variant. In the absence of significant innovation in COVID-19 treatment or viral evolution to lower disease severity, we expect survival probabilities would decrease if ICUs or hospitals were to reach maximum capacity. 
medRxiv preprint doi: https://doi.org/10.1101/2020.09.01.20186395; this version posted November 30, 2020. The copyright holder for this preprint (which was not certified by peer review) is the author/funder, who has granted medRxiv a license to display the preprint in perpetuity.

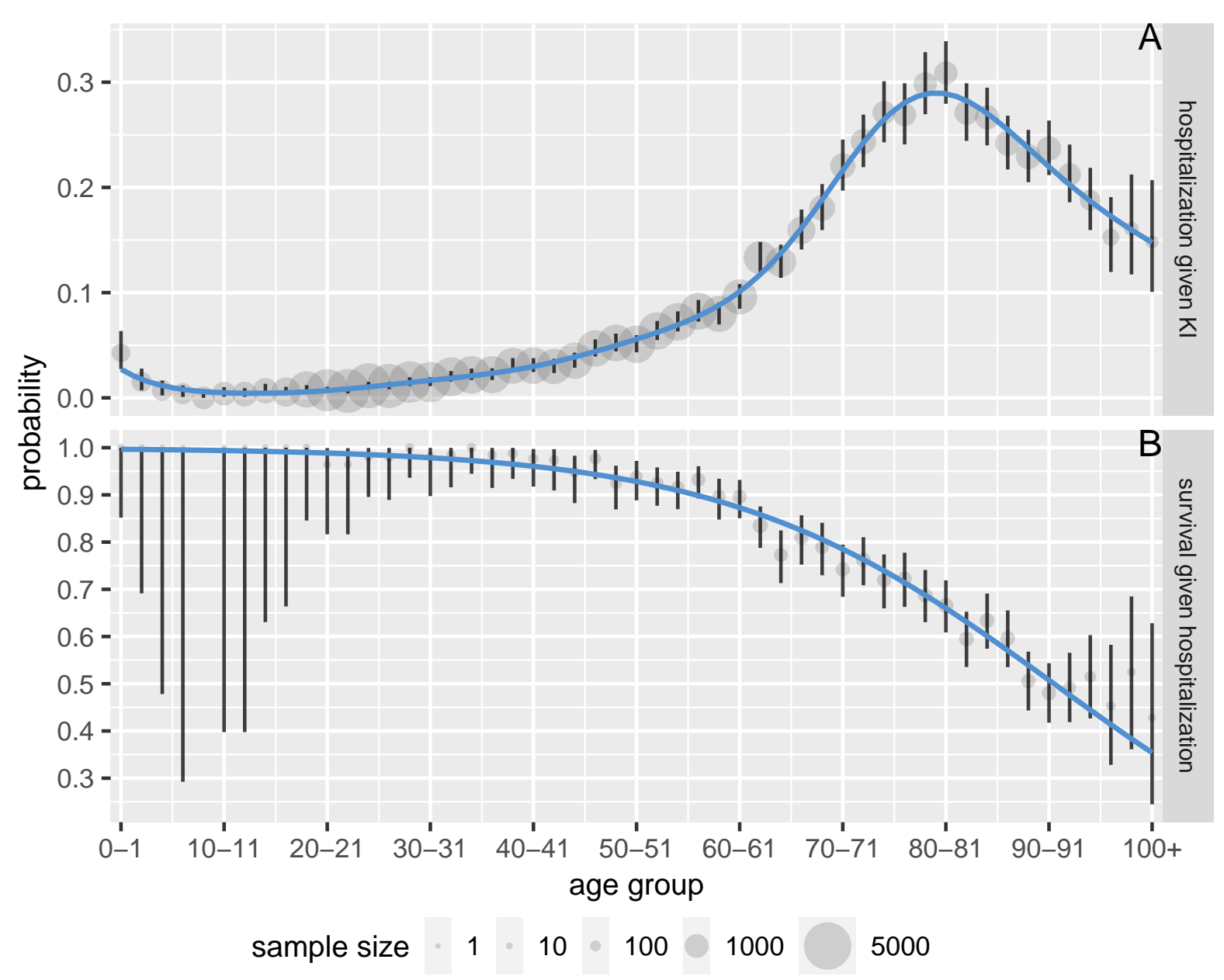

Figure 4: Age-dependent COVID-19 hospitalization probability for known SARS-CoV-2 infection (panel A) and survival probability for hospitalized patients (panel B) in Ontario. We estimate the hospitalization probability using a generalized additive model and the survival probability using a generalized linear model (blue curves; see Methods). Vertical lines give age-specific 95\% binomial confidence intervals and point areas are proportional to samples sizes.

\section{Limitations}

In general, the number of KIs underestimates the true prevalence of SARS-CoV-2 infection for a variety of reasons, including test availability, ease of testing, test accuracy, and difficulties in detecting asymptomatic individuals. The majority of known infections captured in the data analysed in this study occurred when testing guidelines were selecting for sufficiently symptomatic individuals, and so asymptomatic and mild infections are likely underrepresented. Contact patterns in Ontario have changed over the course of the pandemic due to the province's continuing effort to control COVID-19 spread while also supporting the economy. Observed patterns in the age distributions of KIs and deaths may change as the age-specific contact structure and contact rates continue to change. 


\title{
Conclusions
}

We have quantified the age distributions of serious medical interventions for SARS-CoV-2 infection in Ontario, Canada, for the entire period of the regional epidemic. Wide-spread infection control efforts have kept Ontario's healthcare system from being overstretched, yet the probability of survival given COVID-19-related hospitalization is lower than is generally perceived for patients over 40 . Ontario is currently experiencing a significant increase in prevalence of COVID-19; if healthcare capacities were to be exceeded, the distribution of COVID-19-related deaths might expand toward younger ages, where there is already a notable demand for acute care.

The Government of Canada and the Province of Ontario have implemented policies meant to help mitigate SARS-CoV-2 spread while also undertaking a phased reopening [31]. Future work should consider whether the age dependence of SARS-CoV-2 infection risks is changing over time, as the population continues to navigate the pandemic and the testing effort expands. Our study explores only short-term SARS-CoV-2 infection outcomes; future studies should explore the age distributions of long-term morbidities from this infection, so that we may better understand the heterogeneous risks associated with COVID-19. Lastly, all studies relying on known infection counts are subject to bias from how infections are detected via active infection testing. Future work should seek to correct for this bias.

\section{Acknowledgements}

We thank Sarah Morrison for assistance with literature review. We are grateful to the Ontario COVID19 Modelling Table and Science Table (https://covid19-sciencetable.ca/) for valuable discussions. Data were kindly provided by Public Health Ontario. We thank ICES for providing access to data used for preliminary analyses.

This study was supported by the Ontario Health Data Platform (OHDP), a Province of Ontario initiative to support Ontario's ongoing response to COVID-19 and its related impacts. The opinions, results and conclusions reported in this paper are those of the authors and are independent from the funding sources. No endorsement by the OHDP, its partners, or the Province of Ontario is intended or should be inferred.

\section{Funding}

DJDE, BMB, and JD were funded by the Natural Sciences and Engineering Research Council of Canada, the Michael G. DeGroote Institute for Infectious Disease Research at McMaster University, and the Public Health Agency of Canada.

\author{
Abbreviations \\ SARS-CoV-2: Severe Acute Respiratory Syndrome Coronavirus 2 \\ KI: Known Infection \\ COVID-19: Coronavirus Disease 2019 \\ ICU: Intensive Care Unit \\ CCM: Case and Contact Management \\ OLIS: Ontario Laboratories Information System
}


medRxiv preprint doi: https://doi.org/10.1101/2020.09.01.20186395; this version posted November 30, 2020. The copyright holder for this preprint (which was not certified by peer review) is the author/funder, who has granted medRxiv a license to display the preprint in perpetuity.

All rights reserved. No reuse allowed without permission.

\section{Availability of data and materials}

Data and source code for all analyses will be provided in an Open Science Framework repository upon publication of this manuscript.

\section{Ethics approval and consent to participate}

The study received ethics approval from the Health Sciences Research Ethics Board at the University of Toronto.

\section{Competing interests}

The authors declare that they have no competing interests.

\section{Consent for publication}

Not applicable.

\section{Authors' contributions}

IP and DJDE designed this research project, performed the data analysis, and drafted the manuscript. BMB provided specific guidance for statistical analyses. All authors discussed and interpreted the results, revised the manuscript, and approved the final version for publication.

\section{References}

[1] Ontario Confirms First Case of Wuhan Novel Coronavirus [Press Release]. Ontario Newsroom, Government of Ontario. https://news.ontario.ca/mohltc/en/2020/01/ontario-confirms-firstcase-of-wuhan-novel-coronavirus.html Accessed 17 Jun 2020

[2] Novel Coronavirus (2019-nCoV) Situation Report - 1. World Health Organization. https: //www.who.int/docs/default-source/coronaviruse/situation-reports/20200121-sitrep1-2019-ncov.pdf Accessed 31 Jul 2020

[3] COVID-19 in Ontario: January 15, 2020 to July 29, 2020 (Daily Epidemiologic Summary). Public Health Ontario. https://www.publichealthontario.ca/-/media/documents/ncov/epi/2020/covid19-daily-epi-summary-report.pdf?la=en Accessed 31 Jul 2020

[4] Davidson, S.: Ontario Declares State of Emergency Amid COVID-19 Pandemic. CTV News. https://toronto.ctvnews.ca/ontario-declares-state-of-emergency-amid-covid-19pandemic-1.4856033 Accessed 31 Jul 2020

[5] Reopening Ontario in Stages. Government of Ontario. https://www.ontario.ca/page/reopeningontario-stages Accessed 21 Nov 2020

[6] Ontario Students Begin Return to Class Today as Some Boards Reopen Schools. CityNews. https: //toronto.citynews.ca/2020/09/08/some-ontario-schools-reopen/ Accessed 6 Oct 2020 
[7] Lower Social Gathering Limits Adopted Provincewide to Help Stop the Spread of COVID-19 [Press Release]. Ontario Newsroom, Government of Ontario. https://news.ontario.ca/en/backgrounder/ 58398/lower-social-gathering-limits-adopted-to-help-stop-the-spread-of-covid-19 Accessed 6 Oct 2020

[8] Ontario Implementing Additional Public Health and Testing Measures to Keep People Safe [Press Release]. Ontario Newsroom, Government of Ontario. https://news.ontario.ca/en/release/58645/ ontario-implementing-additional-public-health-and-testing-measures-to-keep-peoplesafe Accessed 6 Oct 2020

[9] New COVID-19 Precautions at Long-Term Care Homes [Press Release]. Ontario Newsroom, Government of Ontario. https://news.ontario.ca/en/release/58680/new-covid-19-precautions-atlong-term-care-homes Accessed 6 Oct 2020

[10] Ontario Taking Further Action to Stop the Spread of COVID-19 [Press Release]. Ontario Newsroom, Government of Ontario. https://news.ontario.ca/en/release/59305/ontario-taking-furtheraction-to-stop-the-spread-of-covid-19 Accessed 29 Nov 2020

[11] Wu, Z., McGoogan, J.: Characteristics of and important lessons from the coronavirus disease 2019 (COVID-19) outbreak in China: summary of a report of 72314 cases from the Chinese Center for Disease Control and Prevention. JAMA 323, 1239-42 (2020). doi:10.1001/jama.2020.2648

[12] Davies, N.G., Klepac, P., Liu, Y., Prem, K., Jit, M., Pearson, C.A.B., Quilty, B.J., Kucharski, A.J., Gibbs, H., Clifford, S., Gimma, A., van Zandvoort, K., Munday, J.D., Diamond, C., Edmunds, W.J., Houben, R.M.G.J., Hellewell, J., Russell, T.W., Abbott, S., Funk, S., Bosse, N.I., Sun, Y.F., Flasche, S., Rosello, A., Jarvis, C.I., Eggo, R.M., working group, C.C.-.: Age-dependent effects in the transmission and control of COVID-19 epidemics. Nature Medicine 26(8), 1205-1211 (2020). doi:10.1038/s41591-0200962-9

[13] Mizumoto, K., Omori, R., Nishiura, H.: Age specificity of cases and attack rate of novel coronavirus disease (COVID-19). medRxiv (2020). doi:10.1101/2020.03.09.20033142. https://www.medrxiv.org/content/early/2020/03/13/2020.03.09.20033142.full.pdf

[14] Onder, G., Rezza, G., Brusaferro, S.: Case-fatality rate and characteristics of patients dying in relation to COVID-19 in Italy. JAMA 323, 1775-76 (2020). doi:10.1001/jama.2020.4683

[15] Zhang, Y., The Novel Coronavirus Pneumonia Emergency Response Epidemiology Team: The epidemiological characteristics of an outbreak of 2019 novel coronavirus diseases (COVID-19) - China, 2020. China CDC Weekly 2, 113 (2020). doi:10.46234/ccdcw2020.032

[16] Medford, A., Trias-Llimós, S.: Population age structure only partially explains the large number of COVID-19 deaths at the oldest ages. Demographic Research 43(19), 533-544 (2020). doi:10.4054/DemRes.2020.43.19. https://www.demographic-research.org/volumes/vol43/19/4319.pdf

[17] Myers, L., Parodi, S., Escobar, G., Liu, V.: Characteristics of hospitalized adults with COVID-19 in an integrated health care system in California. JAMA 323, 2195-98 (2020). doi:10.1001/jama.2020.7202

[18] Zhao, M., Wang, M., Zhang, J., Gu, J., Zhang, P., Xu, Y., Ye, J., Wang, Z., Ye, D., Pan, W., Shen, B., He, H., Liu, M., Liu, M., Luo, Z., Li, D., Liu, J., Wan, J.: Comparison of clinical characteristics and outcomes of patients with coronavirus disease 2019 at different ages. Aging 12, 10070-86 (2020). doi:10.18632/aging.103298

[19] Li, M.: COVID19-Canada [Dataset]. https://wzmli.github.io/CovID19-Canada/Accessed 22 Aug 2020

[20] Ontario Significantly Expands Hospital Capacity to Prepare for Any COVID-19 Outbreak Scenario [Press Release]. Ontario Newsroom, Government of Ontario. https://www.news.ontario.ca/opo/en/ 2020/04/ontario-significantly-expands-hospital-capacity-to-prepare-for-any-covid-19outbreak-scenario.html Accessed 22 Aug 2020 
medRxiv preprint doi: https://doi.org/10.1101/2020.09.01.20186395; this version posted November 30, 2020. The copyright holder for this preprint (which was not certified by peer review) is the author/funder, who has granted medRxiv a license to display the preprint in perpetuity. All rights reserved. No reuse allowed without permission.

[21] Table 17-10-0057-01 Projected Population, by Projection Scenario, Age and Sex, as of July 1 (x 1,000) [Dataset]. Statistics Canada. https://www150.statcan.gc.ca/t1/tbl1/en/tv.action?pid= 1710005701 Accessed 20 Aug 2020

[22] Population Projections for Canada (2018 to 2068), Provinces and Territories (2018 to 2043). Statistics Canada. https://www150.statcan.gc.ca/n1/pub/91-520-x/91-520-x2019001-eng.htm Accessed 20 Aug 2020

[23] Wood, S.N.: Generalized Additive Models: An Introduction with R, 2nd edn. Chapman and Hall/CRC, Boca Raton, Florida, USA (2017)

[24] R Core Team: R: A Language and Environment for Statistical Computing. R Foundation for Statistical Computing, Vienna, Austria (2019). R Foundation for Statistical Computing. https://www.R-project.org/

[25] Hsu, A., Lane, N., Sinha, S., Dunning, J., Dhuper, M., Kahiel, Z., Sveistrup, H.: Understanding the impact of COVID-19 on residents of Canada's long-term care homes-ongoing challenges and policy responses (2020). Accessed 31 Jul 2020

[26] Ontario Expands Coverage for Care [Press Release]. Ontario Newsroom, Government of Ontario. https://news.ontario.ca/en/release/56401/ontario-expands-coverage-for-care Accessed 1 Sept 2020

[27] Fisman, D.N., Bogoch, I., Lapointe-Shaw, L., McCready, J., Tuite, A.R.: Risk factors associated with mortality among residents with Coronavirus Disease 2019 (COVID-19) in Long-term Care Facilities in Ontario, Canada. JAMA Network Open 3, 2015957 (2020). doi:10.1001/jamanetworkopen.2020.15957

[28] COVID-19 Provincial Testing Guidance Update. Ontario Ministry of Health and Long-Term Care. http://www.health.gov.on.ca/en/pro/programs/publichealth/coronavirus/docs/ 2019_covid_testing_guidance.pdf Accessed 31 Jul 2020

[29] Ontario Opens Up COVID-19 Testing Across the Province [Press Release]. Ontario Newsroom, Government of Ontario. https://news.ontario.ca/opo/en/2020/05/ontario-opens-up-covid-19testing-across-the-province.html Accessed 17 Jun 2020

[30] Ontario Updates COVID-19 Testing Guidelines [Press Release]. Ontario Newsroom, Government of Ontario. https://news.ontario.ca/en/statement/58507/ontario-updates-covid-19-testingguidelines Accessed 22 Nov 2020

[31] Vogel, L.: COVID-19: A Timeline of Canada's First-wave Response. Canadian Medical Association Journal News. https: //cmajnews.com/2020/06/12/coronavirus-1095847/ Accessed 31 Jul 2020 